\title{
Case Report: Primary Orbital Plasmacytoma by Wilson
}

\author{
Wilson $0^{1 *}$ and Emmanuel $\mathrm{I}^{2}$ \\ Departments of Pathology and Ophthalmology, Nigeria \\ *Corresponding author: Wilson 0, Departments of Pathology and Ophthalmology, Nigeria
}

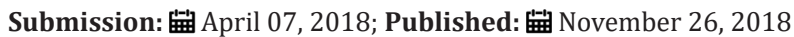

Abstract

Primary orbital plasmacytoma is a rare disease of worldwide distribution. Accordingly, a case report from Nigeria is deemed to be research worthy.

Keywords: Orbit; Plasmacytoma; Worldwide cases; Nigeria

\section{Introduction}

Plasmacytoma of the orbit is a rare lesion. Reports on it have come in alphabetical order from Brazil [1], India [2-4], Indonesia [5], Korea [6], Spain [7] and USA [8]. Now, it is in keeping with the observation made in Birmingham (UK) that the establishment of a histopathology data pool stimulates epidemiological analysis [9]. Therefore, such a pool was established at Enugu, Nigeria, by the Government in 1970 for the service of the Igbo ethnic group $[10,11]$. Being the pioneer pathology, let me present the typical case which was diagnosed personally.

\section{Case Report}

UC, a 25-year-old woman, consulted my co-author, (EI), with the complaint of a hard tumoral mass on the lateral side of the left orbit. It was diagnosed as a malignant tumor and biopsied. The specimen arrived as a lobulated, whitish, soft mass $4 \mathrm{~cm}$ across. Microscopy showed sheets of tumor cells. They were highly mitotically active. The plasma cell look was striking. Plasmacytoma was diagnosed.

\section{Discussion}

My literature searches revealed comparable case reports. They are deemed to be worthy of comparative documentation with special references to the Nigerian epidemiological data. As to the ages, 3 females were aged 42 to 59 years (mean 50 years), while 6 males were aged 43 to 73 years (mean 58 years). Both ranges are a contrast to the Nigeria female aged only 25 years. The orbit was involved 8 times, the eyelids 3 times, and the lacrimal gland once. Like the published majority, the local case was orbital. The mode of obtaining the specimen was not always stated. Biopsy was used 3 times, surgical removal 2 times and cytology once. The local patient was biopsied.

\section{References}

1. Romero IL, Campos FA, Damasceno RW, Vital Filho J, Bison SH (2009) Plasmacytoma of the orbit involving lacrimal gland with secondary transformation into multiple myeloma: Case report. Arq Bras Oftalmol 72(2): 236-238.

2. Chattapadhyav S, Saha A, Mukherjee A, Azam M (2013) Extramedullary plasmacytoma of the orbit. A rare case. Clinical Cancer Investigation Journal 2(2): 163-165.

3. Sen S, Kashyap S, Betharia S (2003) Primary orbital plasmacytoma: A case report. Orbit 22(4): 317-319.

4. Bhadauria M, Ranjan P, Mishra D (2014) Primary orbital plasmacytoma mimicking lacrimal gland tumor. Orbit 33(4): 305-307.

5. Golden N, Niryana W, Saputra H, Dharmayuda TG (2009) Solitary osseous plasmacytoma of the orbit with multiple myeloma: A case report. Neurology Asia 14(2): 171-174.

6. Jung S, Choi SJ, Kang S (2015) Orbital plasmablastic plasmacytoma in multiple myeloma. J Clin Exp Ophthalmol 6: 462.

7. Uceda MA, Blanco G, Saornil MA, Gonzalez C, Sarasa JL, et al. (2000) Extramedullary plasmacytoma of the orbit. Acta Ophthalmol Scand 78(5): 601-603.

8. Adkins JW, Shields JA, Shields CL, Eagle RC, Flanagan JC, et al. (19961997) Plasmacytoma of the eye and orbit. Int Ophthalmol 20(6): 339343.

9. Hsu VJ, Agarwal MR, Chen CS, Rossi C (2010) Iga orbital plasmacytoma in multiple myeloma. Ophthal Plast Reconstr Surg 26(2): 126-127.

10. Macartney JC, Rollaston TP, Codling BW (1980) Use of a histopathology data pool for epidemiological analysis. J Clin Pathol 33(4): 351-355.

11. Basden GT (1966) Niger Ibos: A description of the primitive life, customs and animistic beliefs \& of the ibo people of nigeria, by one who for thirtyfive years, enjoyed the privi. Cass, London, UK. 
(c) (i) Creative Commons Attribution 4.0 International License

For possible submissions Click Here

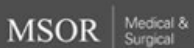 \\ Medical \& Surgical Ophthalmology Research} Ophithimolos:
Rescarch
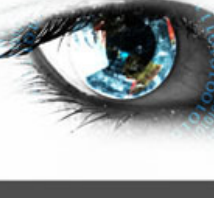

\section{Benefits of Publishing with us}

- High-level peer review and editorial services

- Freely accessible online immediately upon publication

- Authors retain the copyright to their work

- Licensing it under a Creative Commons license

- Visibility through different online platforms 